\title{
Minkowski ou a psicopatologia como psicologia do pathos humano
}

\author{
Mário Eduardo Costa Pereira
}

Ao instalar-se em Paris, logo após o final da Primeira Guerra, Eugène Minkowski introduziria no contexto psiquiátrico francês uma visão inovadora da psicopatologia, que deixaria marcas definitivas nessa disciplina.

Nascido em São Petersburgo, em 1885, Minkowski era oriundo de uma família judaica que migraria da Lituânia para a Polônia quando ele ainda era criança. Inicia sua formação médica em Varsóvia, mas a forte repressão política ali desencadeada, a partir de 1905, levou ao fechamento das universidades polonesas, obrigando-o a concluir seu curso em Munique. Ao lado da medicina, Minkowski dedicava-se igualmente ao estudo da filosofia, que seria continuado durante sua estada na Alemanha.

O início da Guerra, em 1914, fez com que procurasse refúgio em Zurique, tendo sido aceito como assistente de Bleuler, no Burghölzli. Elisabeth Roudinesco comenta que Minkowski guardaria dessa experiência suíça "uma certa hostilidade da psicanálise. [Ele] reconhecia o gênio de Freud e a importância de sua descoberta, mas não estava de acordo com sua teoria da sexualidade (...) [considerando] que a abordagem da loucura deveria ser feita sob a autoridade do olhar médico" (Roudinesco, 1986: 420). Entretanto, sua atitude crítica diante da psicanálise jamais constituiu uma oposição "por princípio” e referia-se mais às implicações éticas de certos pressupostos freudianos e ao comportamento público de certos analistas. Teve, en- 
tres esses, vários interlocutores próximos, tais como Otto Rank e Paul Schiff, psiquiatra pertencente ao grupo da Évolution Psychiatrique.

O pensamento de Minkowski foi fortemente marcado pela fenomenologia, por intermédio do estudo de Husserl, Heidegger, Bergson e, sobretudo, de Binswanger. Por meio desse percurso intelectual, o psiquiatra polonês foi um dos introdutores, na França, das contribuições de Bleuler sobre a recém-criada "esquizofrenia” e da Daseinanalyse binswangeriana. Esta propunha-se, baseada na filosofia de Heidegger, a descrever e a compreender as estruturas fundamentais da presença humana, sob suas formas malogradas, tal como estudadas pela psicopatologia.

Contrário a qualquer reducionismo objetivista dos fenômenos psíquicos, sua metodologia fenômeno-estrutural baseava-se no encontro mais próximo possível com o humano. A partir daí, seu método não se limitava a descrever a experiência vivida [Erlebnis] pelo indivíduo em sofrimento psíquico, ligando-a, também, a “... uma estrutura que organiza as perturbações, a uma forma, a um fundo mental concebido de modo dinâmico numa perspectiva que pode ser, no plano fenomenológico, qualificada de genético-estrutural” (Beauchesne, 1989: 123).

Tendo sido um dos criadores e principais expoentes do grupo Évolution Psychiatrique, ao lado de Henri Ey e Paul Schiff e, posteriormente, de Pichon e Lacan, Minkowski foi defensor de uma psiquiatria humanista, crítica e aberta ao debate das diversas correntes que nela se encontram. Em relação especificamente a Lacan, Minkowski teve sobre ele uma influência decisiva por meio de seus estudos fenomenológicos e por, de certa maneira, ter-lhe apresentado o pensamento de Heidegger.

Sua visão da psicopatologia consiste antes de mais nada em uma tomada clara de posição na velha antinomínia que domina essa disciplina: diante da questão de se esta constituiria uma psicologia do patológico ou uma patologia do psicológico, Minkowski não hesita em alinhar-se com a primeira proposição. Contudo, trata-se antes de tudo, para ele, de poder dar ao fato pático - verdadeiro objeto da psicopatologia - seu justo estatuto. Dentro dessa visão, o fenômeno psicopatológico não estaria delimitado por seu caráter mórbido ou doentio, mas por constituir uma outra forma de ser (“être autrement”, Minkowski, 1966: 81). Além disso, mesmo fenômenos psíquicos sistematicamente negligenciados pela psicopatologia médica tradicional, por não terem um caráter intrinsecamente patológico - como a nostalgia e a avareza -, constituem, para Minkowski, objeto de legítimo interesse para o psicopatólogo. Tratam-se de "fenômenos essenciais da existência" (Minkowski, 1966: 806) e têm seu valor pelo potencial de sofrimento e de "perda” que comportam.

As principais contribuições de Minkowski à psicopatologia são seus estudos sobre a melancolia esquizofrênica, sobre o tempo vivido, sobre o problema da espacialidade e o célebre Tratado de psicopatologia, de 1966. 
O texto aqui apresentado constitui um extrato das "Considerações finais" de seu Traité de psychopathologie. Nessa obra maior do pensamento psicopatológico, Minkowski defenderá a autonomia da psicopatologia em relação à medicina e considerará a loucura como um ruptura do diálogo humano, na qual o sujeito abstrai-se da possibilidade de se modificar pela dialética, instaurando um "drama” (cf. expressão do próprio Minkowski) em sua existência.

O terceiro livro do Traité encerra-se com uma reflexão de Minkowski sobre o problema do sofrimento. Ali, ele sustenta que o sofrimento "faz mal”, “dói” e é, em si mesmo, "indesejável”. Embora não tenha qualquer caráter de necessidade, não há ninguém que passe pela vida sem conhecer o sofrimento, podendo mesmo dele se beneficiar, no sentido de um aumento de compreensão sobre a própria existência. Dessa forma, o sofrimento nos revela "o aspecto pático (e não patológico) da existência” (Minkowski, 1966: 805), colocando a interrogação sobre a sabedoria que, eventualmente, se pode dele retirar: "Por si mesmo, o sofrimento não tem sentido - como poderia ter algum? - mas através dele coloca-se o problema do sentido da vida" (ibid.: 802).

Minkowski pertence a um grupo de psiquiatras - ao lado de Erwin Strauss e Victor Von Gebsattel, entre outros - que, servindo-se da fenomenologia e do pensamento heideggeriano, buscou constituir uma psicopatologia não-especulativa, baseada numa rigorosa abordagem fenomenológica da experiência clínica e numa postura ético-científica resolutamente humanista. As contribuições de Minkowski, como o texto aqui traduzido permitirá de entrever, são incontornáveis para os que se dedicam a refletir sobre os fundamentos da psicopatologia e sobre a especificidade de seu objeto.

\section{Referências Bibliográficas}

Beauchesne, E. História da psicopatologia. São Paulo: Martins Fontes, 1989.

Minkowski, E. (1966). Traité de psychopathologie. Plessis-Robinson: Institut Synthélabo, 1999.

Postel, J. \& Quetel, C. (orgs.). Nouvelle histoire de la psychiatrie. Toulouse: Privat, 1983. p. 680-681.

Roudinesco, E. Histoire de la psychanalyse en France. Paris: Seuil, 1986. t. I. Roudinesco, E. \& Plon, M. Dicionário de psicanálise. Rio de Janeiro: Jorge Zahar, 1999. p. 516. 